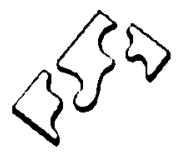

\title{
Remembering the Childhood Loss of a Mother
}

Darlene Witte

Graduate Student

Department of Elementary Education

University of Alberta

I have been an elementary school teacher for 16 years, and returned to the University of Alberta in 1988 to begin work on a masters degree. When that was completed I continued on with doctoral work, fulfilling the requirements for candidacy in the spring of 1991. Early in my MEd program I was introduced to the writing of Langeveld "The Secret Place of the Child" in Phenomenology + Pedagogy). Fascinated by the evocative language of this classic work, I decided to further explore phenomenological traditions. I was fortunate enough to be able to study with Max van Manen early in my doctoral program. Later I took a course with Bas Levering (The University of Utrecht) when he visited the University of Alberta during the summer of 1990. His work in conceptual analysis and ordinary language philosophy further influenced my thinking. My present research involves exploring the cultural narratives implicit in our understanding of literacy and children's play.

It was Christmas morning. I opened a small box that had been placed for me under the tree. Inside was a doll with brown hair and blue eyes dressed in a hand crocheted purple and white outfit. She wore a hat that tied under the chin, bootees with ribbons, a dress, and a sweater. I held that doll and knew she was mine, a part of me. I touched her clothes and her hair. I held her close and rocked her gently.

As I touched this doll I felt my body open up into a deep, empty well. Into that deep emptiness flooded a sense of utter peace, a quiet, full feeling of wholeness. Throughout the rest of that day it seemed that I walked perfectly united with a world that was fundamentally firm, profoundly gentle, and elementally safe. I had a sense of there being no world other than this one in which I was immersed in wellness. In this universe my body, my thoughts, and my sense of being in the world formed an absolute centre and were of prime importance. My self seemed to be both enlarged and joined to an other person. Whatever or whoever this other was it was separate from my own being while essential to both my being and what I knew of myself.

I felt drawn to hold the doll from time to time throughout that Christmas day. Whenever I saw or touched her, an echo of that welling sense of another reverberated through me. I knew this other contained elements 


\section{University of Alberta}

that both defined and shaped what I was, what I knew, and what I would need. Who and what was this other to whom I suddenly felt so connected and by whom I felt so completed when I opened that box? How was it that I suddenly felt safe, coupled not only to myself but also to something or someone beyond myself?

On the Christmas morning described here I was 32 years old and it was the second time in my life that I had found this doll placed for me under a Christmas tree. The first time I had received this doll I was seven years old and she had been placed there by my mother. Then the doll was brand-new and wore a white nightgown. She had pink cheeks and long black eyelashes that framed blue eyes that opened and shut. The second time I found her she had been freshly dressed and placed there by my sister-in-law. The doll's plastic skin was blotchy, the eyelashes were gone, and her hair was faded and stiff, but I did not see that. I saw, felt, and knew her as the doll my mother had given me many years before. On this second Christmas morning it seemed that the context of a long forgotten doll and the appropriately evocative setting brought forth a buried awareness of what my feelings on that original Christmas morning may have been. My mother had died not long afterward. With the renewal of these memories as an adult, I realized that it was she who had made Christmas the warm childhood event that it had been. I also became newly aware of what her presence in my life may have been.

\section{When Memory Assails Us}

There are occasions when another time in life rushes in uninvited. Past and present become confused. Mind and body seem to momentarily forget present time and present space. We have the feeling that an emptiness has just been filled, and the fresh indwelling of that memory leaves us changed. We are more ourselves for having had this visitation. Altered, deepened, stirred in some way, we experience this kind of remembering as dwelling in the fullness of being there. In the remembering a part of us relives. And in the reliving as with living itself, there is a mingling of the bitter with the sweet. The welcome may be mixed with the unwelcome.

When it happens that a visit from the past assaults our senses and draws us suddenly away from the present, such a childhood memory can catch us unaware. In the creak of a door when we enter a room, the rustle and scent of paper when a forgotten box is opened, or when the light catches the sky in a particular way and our eyes suddenly see a scene that stood before us in a time long since past, we may meet ourselves again. Thus our own childhood lingers within us and may be released by any of a thousand gentle sensory intrusions. These points of release are very personal. They are the sudden scent of sun on roses, or the smell of fresh bread or new leather. Or the renewed presence of a childhood toy such as a doll. They are the unbidden events that convey us to another time and another place. Memory stored becomes memory stirred, and it is as if 
time dissolves. What is it to remember in this way, when we find ourselves lifted out of where we are into a space we had thought we had long left behind? It is as if time suddenly holds us prisoner of its backglancing. We stand caught in the grip of long ago. Our ears strain to hear a voice long since gone silent, our hand reaches for a hand that is not there, or our arms hold themselves out to catch into their circle a shadow that seems to walk beside us, just beyond touching.

This article is an exploration of the phenomenon of remembering a parent who has died. The personal narrative into which $I$ have gathered this experience is my way of placing myself and the lost one into a story. Therefore, it is a way of understanding my own experience. It provides a frame for memories and a way for me to see my own going on with life.

\section{When Remembering is Unvoiced}

My relationship with my mother was violently and abruptly severed a few days before my eighth birthday when my family was involved in a car accident in which she was critically injured. We never shared Christmas again. I remember falling asleep beside her on the seat while we were driving. With my body lulled by the hum of rubber tires on smooth asphalt and the warmth of afternoon sun on my cheek, I remember saying, "Can I put my head down?" I curled myself up on the seat with my head cushioned on her lap, and as I fell asleep I felt wonderfully safe and deeply warm.

This article explores memories of my mother that have been carried forward within me and questions the role that they play. There are some seemingly isolated scenes that in themselves do not seem that they could be important to a lifetime. I remember hurrying with her to catch a bus. My legs seemed so short and my feet so slow. She was so tall and moved so quickly. I ran while she walked, needing two of my steps for one of hers. I remember standing beside the kitchen table, watching her stir a bowl of red Jell-O. The air smelled warm and sticky and sweet. She handed me the spoon and asked if I would like to "finish the job." There was a day when I was playing in the yard while she planted pansies nearby. She explained that pansies have tiny faces painted on their petals. Another memory holds us clapping and singing a rhyme about a Polly and a dolly that was "sick, sick, sick." Her voice was so sure of the words and mine was trying to catch up. I recall being in the living room with her one afternoon. I retain a sense of the quality of light that patterned the air and the walls that day, how the sun printed warm spots on the floor and how those spots seemed to grow cool as soon as I would lie on them. I remember wondering why the sun did not make skin feel as warm as the floor, why my mother liked to read the newspaper, and why newspapers rattled. And I knew that my mother could make anything she wanted to make, like doll sweaters out of pink wool. 


\section{University of Alberta}

While I did not often cry for loneliness or for the loss of my mother during the years of my childhood, I would weep for hours on Christmas days without knowing why, without being able to stop, and without being able to bring words to my feelings. Was it because I missed my mother? If so, I did not understand that it was she for whom I wept. Did I remember the tenor of other Christmases and think that the day just made itself out of its own magic? Perhaps. It was a magic that never had came again after her death. As a child I never quite realized why.

Certain memories seem to ride along just beneath the surface of our lives where everyday awareness may find them at will. Even though the remembered incidents may seem rather insignificant and our orientation to them rather shallow, we have a sense that they could be deepened and enriched by recalling and revisiting them through reflection. The memorability of these events is that they were born of our experience. They are our connection with ourselves and our own knowledge of the past. Because we have these memories we know that we are legitimately and solidly a part of the story of our own lives. We may rarely speak of them. There is an element of eternal, sacred privacy about them. It is not that they cannot be discussed with others, but there seems to be little point in sharing them. No sharing quite seems to retain the appropriate richness. When we try to explain how the red Jell-O smelled hot and sticky and sweet while our spoon carefully stirred, the listener seems to already know what we mean but be equally unable to find adequate words, being perhaps caught by the moment in a similar memory of their own. Trying to share these memories requires an uncomfortable effort that seems only to emphasize the distance between our sense that these incidents immersed us in events so significant that the spoken word cannot quite recapture them. These form our private hoard, which is rich and golden. Perhaps these memories are best enjoyed in silence. We do not speak them because they need not be spoken. But there are others that seem to draw us back into themselves for an even deeper purposethose memories that rise up from some deeper place, prodding our consciousness with questions of why that draw awareness forth into language.

\section{In Memoriam: To Remember the Lost}

Mother died on a day when the sun silently poured itself out, an April warmth easing a softness into the snowdrifts and melting them to laughing rivulets that trickled down the hillsides and into the ditches. I was in school, and my father came to get me. He held my hand as we walked across the white concrete sidewalk. His shoes sounded loud, while mine whispered softly. I noticed a strange brokenness to the rhythm of his steps. His tread was usually very firm and steady. He drove us home. In the yard sodden grass, brown and lifeless squelched around my shoes. He said, "Mommy is gone. We have lost her. She died this afternoon. I'm sorry." 
These words set me off on a terrible journey alone, trying desperately to find where it was that she had gone. I remember sensing the strangeness of that moment, where in the same second of time a normal everyday world full of sunshine and laughing water suddenly had frozen black edges. Part of my mind wondered what my father's words meant. I silently spoke them over and over, trying to make them fit into the swirling sick confusion that surged through me, uncontrolled, uncontrollable, and without warning.

Mother had been in hospital for months after the car accident and I had lived every day expecting her soon to come back. How I went into the house, the house I had expected her to come back to, listening for her voice as I always did to orient my coming inside. But I heard only silence. And this time I knew that my hope for this silence to be filled was broken. The air in the house felt cold on my skin, and in the quiet and cold I suddenly felt that my body was the wrong size. I was too big on the outside, too small on the inside, and I felt that I no longer fit in the familiar spaces of the house because everything had abruptly changed. I felt helpless. I was too small, and my voice was lost. My body could not tell me who I was, and my mind did not have the words to say who or what I was. I felt tired and afraid. I wanted to join my mother in the death where she had gone, to hide in the quiet and in the dark and be safe as she was safe. But just as she seemed to be lost, I seemed to be lost as well. I wanted to be found and to find her. I wanted to lie down beside her, wrap my arms around her and wait for her to come back. I hoped that if I waited for her long enough she would hear my silent waiting and would come back and hold me in her arms. She would hold me specially and keep me warm by listening to me and telling me, as she once had told me, that she liked to hear me singing.

It seems that during times of trauma memories pass through our minds in searing, tumbled confusion and are equally an attempt to find the lost one and an effort to locate something within the self. What is the power of these memories in our lives? There is a sense of searching alone and restlessly for something that must be brought back, but the searching is done in the midst of a terrible isolation. This kind of remembering has an aloneness right at its heart. There is a sense of emptiness that rests heavily within the body and weighs down every movement. This kind of remembering has a wandering quality something like that of a mother who has lost a child, or a child who has lost its mother. No comfort comes with this remembering. Every moment only contains a sense of the loss of the beloved, and neither mind nor body can "believe" that the lost one cannot be found. Armstrong (1973) writes of this searching, describing a family of children who did not believe that their mother had died. "They looked first in the kitchen. Then I heard the doors open and close as they swept from room to room, searching for some familiar sign on the landscape of their lives which had become so suddenly strange and unknown to them" (p. 37). The terrain in which we live is so altered by 


\section{University of Alberta}

this kind of loss that even the self seems alien within that scene, and changed in some way. When these memories surround us they have the power to shake us from the inside out, even years later. Our eyes can suddenly fill with tears, and they are the same tears we wept in childhood. Even as we cry we wonder how those events can still be so very much with us.

I had been in hospital too for a week after the car accident in which my mother and I had been separated. Lying in a high white bed in a empty room with silence all around me, one day I suddenly became aware that I wanted to talk to somebody. I pressed the bell to call the nurse and the one who came asked what I wanted. I said... (How could I say I was lonely? I couldn't name that feeling to anyone. I'm not even sure that I knew what the name of that feeling was, but I knew that what I wanted was to talk.) I said, "Could I please have a drink of water?" The nurse answered, "You don't want a drink. You just want attention. Leave the bell alone unless it's something really important." She disappeared from the doorway and I could hear her voice join the chatter of the other nurses at the desk outside my room, down the hall.

Looking back, it seems that from this point on I dwelt in silence. I seemed unable to find another with whom to dialogue as I had with my mother. I felt trapped by silence and unable to reach beyond it. The nurse who would not listen was only the first of many. One of the problems of living with the loss of my mother was finding someone who had an idea of the closeness that I remembered and needed to reconstruct. While my mother's understanding of me had been central to my own understanding of myself, she had also interpreted me to and buffered me from others. She would tell them what she knew of me, and in this she translated me to them. In the same way she would interpret their words and actions to me, helping me to understand the incomprehensible. To my father and others she would recount things I had said or done. They knew me through her eyes, and much of what I knew of them was filtered through her. She heard my language, heard the intentions deep inside me and could name me to the world. She showed me that I had a voice, that my speaking had meaning. And as long as she had heard me, even if it was only occasionally, it did not seem to matter whether others did or did not. But when she was gone I felt as if I no longer had a way to make sense of living. From then on my experiences as well as my self always had a sense of being unformed, unfinished, and unsafe. It was as if the memory of closeness with her formed a wall of silence around my world.

\section{Living with Loss: The Forgettable and the Unforgettable}

Through our memories we may find what is lost, and in that finding we may find safety. To remember is to reenter the past and to be with that which is no more. In this way silence allows that past to speak again. Living on with such a loss requires that we find that aloneness can in itself be whole. Memory can provide continuity to the story of our being 
with the one who is gone. In this way our memories may reorient our lostness by gathering up the threads of the story. Giving a voice to the loss also gives it a place and a time to be. Remembering serves our sense making, and the connections made reshape our pain until the loss may be accepted as a sense of peace.

When all that is familiar and known is changed by an event such as the death of a parent, to live with the loss of that shared closeness is to know that memories and the acts of remembering are the only reprieve possible from final silence. In memories the dialogue of being together can carry on, changed by the fact that it is now one-sided, but nevertheless the dialogue can carry on. There is a saying that the loved one, though in the grave, "will always be in our hearts." The indwelling of remembrance softens the blow of the finality of death and allows us to be linked with what is lost so that we ourselves may not be lost into that death. These memories hold us in place in the world and allow us to be reoriented to a present that accepts and contains the loss but in which we are not consumed by that loss.

Even as I sought a dialogue with memory in order that my living on could reach beyond the silence, my thoughts, as Robinson said, were "thronged by silence" (p. 219). In Robinson's novel Housekeeping, Ruth also loses her mother at an early age. In the life of this character, as in mine, the dialogue in life with the mother is interrupted and replaced by a dialogue with memory, and those memories are staged in silence. The mother's voice is missing and no other takes her place.

When I would walk into the house after school, no one was there. The rooms would be cool and quiet and exactly as they had been left that morning. There was no presence of an Other there to warm this space with the clatter of ongoing work, or the smell of supper cooking. She did not call out, "Hello," when the door opened. And yet her presence seemed to hang just beyond the air, almost touchable, and that at any moment I could hear her call to me, her voice sounding as if she were speaking through a wall. I imagined that if I could only listen hard enough and wait long enough I would hear her call. There were times when my whole body concentrated on listening for her, some sixth sense of me also straining to hear the call that never came.

When such memories are addressed only by an empty silence, they never become shrouded or gentled by the peace of resolved questions. They never become safe, but these memories of memories continue to haunt, becoming a darkness that lurks behind every thought.

\section{The Dialogue Beyond Silence}

One day I remember thinking that I wanted to spend a few quiet minutes before going to bed. I felt empty, as if I wanted to talk to someone about my thoughts and feelings, to review the day and come to a statement about myself and the day as it had been and hear another voice reflecting 


\section{University of Alberta}

my experience back to me, reshaped by their listening. Robinson (1980) describes this as wanting to "hold things in place with a web of words" (p. 200 ). When experience and the meaning of experience is shared, the silence is filled. But there was no one there to talk with me about my day at school, about making supper or doing the dishes. My father and brother had already gone to bed. There was no one but the silence, so I reached out into that silence. I could not remember actual words that my mother had said to me. I could only faintly remember the sound of her voice. My memories scrabbled with each other. Although I tried hard not to forget her, every day it seemed that I knew her less than I had the day before. What did her face really look like? How did her voice really sound? I stood listening, wanting to hear her speak again. I had wrapped a robe around myself, a garment that had belonged to her. I had turned off the lights and was just standing alone in the dark room. I remember the silence and the dark all around me, and I remember trying to force my mind to comprehend that no matter how hard I listened, silence would be all that I would hear.

It is silences such as these that remembrance seeks to mitigate, and though the memories are inadequate they are all we have. The emptiness is filled by an ever-present sense of what has been lost. It remains impossible to make the loss be forgotten by removing her from memory or mind. In writing of a child's loss of her mother, Robinson (1980) writes that in this filling,

Every memory is turned over and over again, every word, however chance, is written in the heart in the hope that memory will fulfil itself, and become flesh, and that the wanderers will find a way home, and the perished, whose lack we feel, will step through the door finally and stroke our hair with dreaming, habitual fondness, not having meant to keep us waiting long. (pp. 194-195)

I still wait. As a child I never lost the sense that my mother would come back. Because of this I waited for her. While I waited I would count the tiles on the floor, going forward and backward and by twos, fives, and tens. I would review the spots on the wall, cracks in the sidewalk, and shadows on the grass. It seemed that as the years went on I lived more and more in moments after they had passed, reflection and introspection becoming part of the waiting and part of the filling of the silence. While other people seemed to be able to dwell in times and spaces of their own creation or that they created with others, it seemed that I had no such world. I was homeless even inside my own skin and always separated from the world around me. The memories of being with her drifted through me, unable to connect with each other to form a whole sense of presence.

While I waited I would watch myself going to school one more day, doing my homework one more time, peeling one more pot of potatoes for one more supper, ironing one more load of laundry, aware that as I did so 
seconds were passing, hours were mounting, and days were bringing me closer to-to what? To finding her again? The habit of waiting for her, and the emptiness of dwelling with an expectation that could neither be fulfilled nor replaced presented me with life as a series of moments that, in Robinson's words were "most significant for what [they did] not contain" (1980, p. 214).

Perhaps it is only an illusion that memory chiefly serves to stir time past. When I had thought that this silence would never be broken and thus mend again into a dialogue, my child was born. As I held Robin in the quietness of our hospital room, there was a moment when memory seemed to live again. In holding this child I felt the presence of my mother. I knew that somehow I was her and she was me, and together we were holding this baby. I sang to Robin, and she turned her small face toward me, opened her mouth, and tried to match her voice to mine. In that moment "there was the hush and solemnity of incipient transfiguration" (Robinson, 1980, p. 196). The past and the future became presentness, and I saw and remembered the mothering of my mother through touching the body and being of my child. I became to Robin the closeness that my mother had been to me. When I held her there was a healing of the emptiness, a sense of being connected to what had been irretrievable. Dialogue resumed.

\section{When the Silence is Broken}

Implicit knowing such as this can be revealed in actions that we know to do, but do not know how or from where we knew to do them. These actions arise through our knowing like a sunrise over barren land and bring with them a light of their own that is rosy and refined. Our memories become articulate in such actions. This infusion of the known reminds us what it was to have been there, to have heard or done or known in another time and another place. I know how to mother because my bones remember that a mother once held me. I have forgotten the words with which my mother and I shaped our being together, but I have not forgotten that to dialogue means to hold another human being's words as I would a treasure and ponder their meaning.

Robinson (1980) also writes that "prophecy is only a brilliant memory" (p. 192). She says that "memory pulls us forward" into the common experiences of humanity. In living we learn what it is to be human, to know the joys and the terrors of homo sapiens, and to think on these things. And in our doing, we remember.

In one of the last conversations I had with my mother I asked her to tell me about my name. She said, "It means 'dearly beloved.' That's what you are." Then I asked about my middle name, Laurel. She answered, "the Greeks crowned their poets with laurel leaves ... I was always a good writer. People told me that I had a way with words. I could write pages and pages without ever having to change a word. When I was ready to 


\section{University of Alberta}

write it would just all come ... but I couldn't write poetry ... When I named you I thought of the laurel leaves the Greeks used, and I thought that perhaps you would be a poet."

To name a child is to give that child meaning. To act as prophet-mother is to know the child's soul before she knows it herself. Robin Eileen Johanna is a shining, a light, a gift of God. Most of all, She Is. She is like my mother and yet not like her, like me and yet not me in her eyes and her smile, her way of being, of listening, and of being able to hear that there is something behind, ahead, inside, and around any words that are said.

Meaning is itself the child of knowing and is achieved through purposeful, lingering, remembering. Memory. Memoire. Memoria. And prophecy. The present is linked with the past and with the days still to come. The sense we have of memory is that it can enrich us and make us more deeply known to ourselves, more in tune with the inner task of coming to know what it means to be alive and to be human. In joining time present and time future with the past, the narrative of our lives is enriched. The acts of knowing our own knowledge (Maturana \& Varela, 1988) are the acts of reflection where sense is made of our experience. Memories are as echoes that drift in the back of our minds. Our thoughts surround these words and reverberate as we dwell in them. As we inhabit the connections and patterns of our own lives, memory becomes more than a simple recollection of facts. Memory hints at the possibility of a coming song, a brilliant prophecy that holds steady our sense of the going-on of life and our place in that on-going.

\section{References}

Armstrong, W.H. (1973). Through troubled waters. New York: Signet Classics. Maturana, H., \& Varela, J. (1988). The tree of knowledge. Boston, MA: Shambala. Robinson, M. (1980). Housekeeping. Toronto, ON: McGraw-Hill Ryerson. 